\section{Dietary Patterns and Their Impact}

\author{
by Ulrike Eberle, corsus - corporate \\ sustainability
}

Dietary patterns have changed a lot in the past decades. In particular, in the OECD countries there has been a dramatic increase in the share of animal-derived products such as meat and dairy products since the beginning of the 1950s. The same development can nowadays be observed in transition and developing countries, and it is predicted that meat and dairy consumption will continue to rise. Not only dietary patterns have changed, but eating habits have also changed considerably. Consequently, the demand for convenience food and eating out of home is on an upswing. Despite some opposing tendencies, such as a growing market for organic food, vegetarianism and veganism, the overall trend has led to an increase in environmental burdens and to negative impacts on health. Given these adverse effects, a shift towards a sustainable consumption of food is urgently necessary and sustainable food choices should become the standard in the near future.

Die Ernährungsmuster haben sich in den letzten Jahrzehnten stark verändert. Besonders in OECD-Ländern ist der Anteil von Lebensmitteln tierischen Ursprungs wie Fleisch und Milchprodukte seit den 1950er Jahren erheblich gestiegen. Die gleiche Entwicklung kann heutzutage in Schwellen- und Entwicklungsländern beobachtet werden und es wird angenommen, dass der Fleisch- und Milchkonsum weiter zunehmen wird. Aber nicht nur die Ernährungsmuster, sondern auch die Essgewohnheiten haben sich stark verändert. Die Nachfrage nach sog. „ConvenienceProdukten" und der Außer-Haus-Verzehr sind im Aufschwung. Trotz einiger gegenläufiger Tendenzen wie dem wachsenden Markt für ökologisch erzeugte Lebensmittel, Vegetarismus und Veganismus, führt der dominante Trend weiterhin zu einer Zunahme der Umweltbelastungen und negativen Auswirkungen für die menschliche Gesundheit. In Anbetracht dieser negativen Effekte wird ein Wandel hin zu einem nachhaltigen Lebensmittelkonsum als dringend notwendig erachtet. Die Entscheidung für nachhaltige Lebensmittel sollte in naher Zukunft Standard werden.

\section{Introduction}

Today in the Western industrialised nations nearly every food item is available all year round and is produced and distributed globally (Eberle 2012; Oosterveer/Sonnenfeld 2012). It is quite normal for people in these countries to purchase food that is out of season or not produced locally. This has not always been the case throughout history, even though trade with spices and some food products can be traced back to the ancient world. Even at that time such products were imported to Europe from Eastern and Far Eastern high cultures and influenced considerably the development of European eating habits (Hirschfelder 2001). However, food was mainly produced and consumed locally. Nowadays, this is quite different. While a huge part of the food Germans eat is produced in Germany or Europe, we cannot presume that it was delivered from the closest farm as was common practice several decades ago.

Just as with trade channels, our eating habits and dietary patterns have also changed considerably in the past decades. Consequently, the demand for highly processed food and for convenience food as well as for eating out is on an upswing. These trends correlate well with the fact that the time spent purchasing or eating food has also diminished over the past decades, as has the competence in housekeeping, regarding the adequate storage of food and the preparation of meals. Knowledge about agricultural production and food processing has also declined. Examples are topics such as how food is grown, which crop is in season, what kind of crops can be cultivated in which region, how food is processed. The general knowledge that was present a few decades ago has meanwhile withered in many parts of the population. Consumers had become estranged from food production (Hamermesh 2007; Eberle et al. 2006).

\section{Changing Dietary Patterns}

Changes in diets can be shown impressively using the examples of pork, eggs, and potatoes: In West Germany in the 1950 s each person ate on average $19 \mathrm{~kg}$ of pork, $7.4 \mathrm{~kg}$ of eggs, and 184 $\mathrm{kg}$ of potatoes per year. Ten years later, the con- 
sumption of pork and eggs had increased to nearly 30 and $13.1 \mathrm{~kg}$, respectively. In contrast, the consumption of potatoes had decreased to $132 \mathrm{~kg}$ in the 1960s (Hirschfelder 2001). Today, the annual consumption of potatoes has decreased further to $60 \mathrm{~kg}$ per person, and pork consumption is nowadays about $40 \mathrm{~kg}$, more than double the consumption in the 1950s. Eggs have remained more or less stable at $13 \mathrm{~kg}$ (BMELV 2010).

At a closer look at the development of diets in European countries, two developments can be observed. One is that the total energy intake has increased by about $15 \%$ over the past decades, and the other that diets, which had been quite different in Southern and Northern European countries in the past, are converging more and more. This means that the intake of free sugars, saturated fats and cholesterol has increased in Mediterranean countries and decreased in Northern European ones. The Mediterranean diet today contains much more meat than four decades ago, apparently even surpassing that of Northern European countries, while some Northern European countries have reached levels of fruit and vegetable consumption that are near to those of Mediterranean countries. Yet some of the traditional characteristics remain, such as the fact that much more pulses and olive oil are eaten in Southern European countries and that the intake of fruit juices continues to be a characteristic in some Northern European countries (Naska et al. 2006; Schmidhuber/Traill 2005). The general dietary changes - more energy intake, a high intake of fat and added sugar, and a high or increasing share of animal-derived food can also be observed in other nations that are part of the Organization for Economic Cooperation and Development (OECD) (Reisch et al. 2013; EEA 2005; OECD/FAO 2011).

Estimates indicate that the intake of meat products in industrialised countries has slowly reached saturation, albeit at a very high level. According to a recent report by the Heinrich Böll Foundation (Badenschier et al. 2013), a stagnation or even a slight decline in meat consumption can be observed in many highly industrialised countries. In the USA, where the largest quantities of meat are eaten per capita, consumption has diminished by $12 \%$ since 2008 . This development is traced back to higher meat prices and reduced purchasing power of households during the economic crisis as well as to the success of health and nutrition campaigns. However, it is likely that this downward trend in industrialised countries will not be sufficient to compensate the growing demand in emerging and developing countries (e.g. Bauhus et al. 2012).

A development quite similar to that in West Germany after the Second World War and also parallel to that in other industrialised nations can today be observed in the emerging and developing countries. Yet it also differs in some aspects. In particular, the speed of nutrition transition - the shift from traditional diets to more Western-oriented diets - is enormous (Popkin 2002). Hence, diets in developing countries today contain fewer cereals, roots and tubers and more meat, dairy products, caloric sweeteners, and oil crops than before. Beneficial dietary shifts from an increasing energy supply are accompanied by unfavourable ones as much higher intakes of edible oils, animal derived food and added sugars. And it seems that the unfavourable shifts are happening much faster than the conducive ones (Mendez/ Popkin 2004). According to the World Health Organization of the United Nations (WHO), this development is strengthened by a combination of growing incomes, population growth, urbanisation, and globalisation but is also affected by cultural influences (Hawkes et al. 2007).

Taking a closer look at the consumption of animal-based foods, it is predicted that consumption will continue to rise in transition and developing countries. The highest growth rates in meat consumption are projected for South and East Asia, where they will be 3 or 6.7 times higher, respectively, in 2030 than in 1964, but nevertheless remaining per person at the lowest level worldwide. Per capita meat consumption is projected to range from $11.7 \mathrm{~kg}$ in South Asia to $100.1 \mathrm{~kg}$ in the industrialised countries in 2030 compared to values of 3.9 and $61.5 \mathrm{~kg}$ in 1964 . Thus, while meat consumption levels will concentrate globally at a high level, the difference per capita will still be at a factor of 8.5 (compared to 15.8 in 1964). Thus, according to the WHO, the world average meat consumption per person is predicted to nearly double from 1964 to 
2030, and the consumption of milk will increase by about $15 \%$ in the same period of time. ${ }^{1}$

According to a current note of the High Level Panel of Experts (HPLE) on food security and nutrition, "economic growth and rising incomes tend to lead first to an increase in the amount of food consumed by individuals and their households and then to an increased diversity in their diets. In turn, this drives an increase in the production of processed and animal-based foods, with implications for crop choice as demand rises for animal feed and for the ingredients for processed food, particularly sugars and fats such as high fructose corn syrup and palm oil" (HLPE 2014, p. 8).

\section{Health Impact}

Since not all humans have equal access to food, calories are unequally distributed among the world's population. Today approximately 870 million people globally suffer from hunger, most of them in developing countries (UN 2013; Millstone/Lang 2008). One of the millennium goals is to "eradicate extreme poverty and hunger" and more precisely to "halve, between 1990 and 2015, the proportion of people who suffer from hunger". From the beginning of the 1990s, a decrease from $23.2 \%$ of the world's population suffering from hunger to $14.9 \%$ of people still being undernourished in 2012 was achieved (UN 2013, p. 10). Due to population growth, the absolute number of people being undernourished remains more or less stable.

At the same time, an increase in the number overweight persons, in obesity and of other nutrition-related noncommunicable diseases like cardiovascular diseases and diabetes can be observed, inter alia caused by changing diets. For example, in most EU countries the rate of obese adults has more than doubled in the last two decades (OECD 2010), a development that is hardly surprising due to the fact that food intake in many EU countries is much more than required for a healthy diet. Worldwide 1 to 1.5 billion people are overweight today, and 300 to 500 million of them obese (Reisch et al. 2013). A reduction in undernutrition has been observed in developing and transition countries in the past decades, but at the same time an increase in the number over- weight persons and in obesity. "Among adult women, overweight now exceeds underweight in almost all developing countries, particularly in the most urbanised countries." (Mendez/Popkin 2004, p. 233)

\section{Increasing Environmental Impact}

The aforementioned changes in dietary patterns and eating habits also influence the environmental burdens correlated with human nutrition. Several studies carried out in the last years show that food consumption in Germany causes about $20 \%$ to $30 \%$ of greenhouse gas (GHG) emissions from private households ${ }^{2}$ and thus are in the same range as emissions of households for transport (Wiegmann et al. 2005). Furthermore, about 2,500 to 4,200 square meters of cropland is used for food production per person and year, including imported food and feed (Wiegmann et al. 2005; Kastner et al. 2012; Meier 2014; Eberle/Fels 2014a). Since the 1960s, GHG emissions related to German food consumption have increased by $15 \%$ per person, agricultural land use has increased by $14 \%$ and the use of water for irrigation by $40 \%$ (Meier 2014).

Worldwide agricultural land use for food production has decreased per capita due to higher yields but has increased in absolute terms due to population growth. In particular, the share of cropland used for the production of animal-derived food products is increasing globally due to dietary changes (Kastner et al. 2012). Worldwide crop irrigation consumes most of the freshwater used, agriculture accounting in some developing countries for up to $90 \%$ of the freshwater used. The pressure on freshwater resources will become even greater with dietary changes due to an increasing need of feed for livestock (Schaffnit-Chatterjee 2009; Nellemann et al. 2009).

The climate impact will grow with the rising consumption of animal-based foods, which generally have much higher GHG emissions than plant-based foods. This is mainly due to the poor conversion rate of the energy content when using cereals as feed compared to the direct intake of cereals by human beings, and to the methane produced in the digestive system of ruminants. A recent study of Scarborough et al. (2014) re- 
vealed large differences between the dietary-related GHG emissions of self selected meat eaters, fish eaters, vegetarians and vegans in the United Kingdom. Starting from an average caloric intake of 2,000 kcal per day, the results showed that a meat diet produces $35 \%$ more GHG emissions than a vegetarian diet. Moving from a high meat diet to a low meat diet would reduce the individual carbon footprint by $920 \mathrm{~kg} \mathrm{CO}$-eq/ year, moving from a high meat diet to a vegetarian diet would reduce the individual carbon footprint by $1,230 \mathrm{~kg} \mathrm{CO}$-eq/year, and moving from a high meat diet to a vegan diet would reduce the individual carbon footprint by $1,560 \mathrm{~kg} \mathrm{CO}$-eq/ year. According to the authors, the annual carbon saving of two adult high meat eaters moving to a vegetarian diet would be roughly equivalent to the carbon footprint of a family driving a ten year old small family car for 10,000 kilometres.

\section{Opposite Tendencies in Diets}

Despite these general trends in dietary patterns, opposing tendencies can also be identified. In industrialised countries, the recurrence of regionally or locally grown food, a growing market share of organically grown food, vegetarianism and new trends like slow food or veganism can be observed (Reisch et al. 2013). Between 1999 and 2012 the organically cultivated agricultural land has more than tripled. Today, about 37.5 million hectares of agricultural land are cultivated worldwide according to the standards of organic agriculture. The main producing countries are Australia (12 million hectares), Argentina (3.6 million hectares) and the US (2.2 million hectares). In the European Union, $5.4 \%$ (9.5 million hectares) and in Germany $6.1 \%$ ( 1 million hectares) of the agricultural land is cultivated organically, while the worldwide average is $0.9 \%$ (FiBL/Ifoam 2014). The increasing demand for organically produced groceries can also help to reduce the environmental burdens of agricultural production. In addition, there is some empirical evidence that a shift to organic food changes the dietary patterns towards diminished meat consumption (Meyer/Priefer 2012, p. 140).

A study carried out by Kearney (2010) about food consumption trends and drivers revealed that the motivation of consumers to purchase organic food, with its strong emphasis on environmental protection and animal welfare, is mainly the assumption that organic food is healthier. This applied for $48 \%$ of the consumers surveyed, while only $16 \%$ said that they buy organic food because it is better for the environment (Kearney 2010).

Another trend is the slow food movement, an organisation founded in 1989 in Italy, today active in about 160 countries worldwide. Slow food envisions "a world in which all people can access and enjoy food that is good for them, good for those who grow it and good for the planet" (http:// www.slowfood.com/international/2/our-philosophy). The main objectives include: food and taste education, conservation of endangered artisanal foods, celebration of regional gastronomic traditions, promotion of responsible agriculture, support for local food systems and addressing hot topics like animal welfare and land grabbing (http://www.slowfood.com/international/1/aboutus). Although the slow food movement is growing, having reached 100,000 members worldwide (http://www.slowfood.com/international/4/ where-we-are), it is still a niche movement but with the potential to influence broader society.

A powerful trend is vegetarianism, a nutritional practice which is quite old and dates back to ancient times. Vegetarianism was given a strong push forward in the past decades by nutritional concerns but also by ethical and to a lesser extent environmental concerns. Furthermore, a new tendency that has emerged in the recent past is veganism. Vegans only eat plant products and dislike any kind of usage of livestock or wild animals for human needs. Today, only a small share of Germans eat vegan. According to Cordts et al. (2013), only $0.3 \%$ are vegans, compared to $3.7 \%$ who are vegetarian. The European Vegetarian Union counts far more vegetarians. Following their estimates, today about $9 \%$ of the Germans and Swiss are "veggies" (http://www.euroveg.eu/lang/en/info/howmany. php). Viewed globally, this is a quite high share, in particular compared to other OECD countries. Worldwide the most vegetarians - both in absolute terms and in relation to population size - live in India. Due to cultural traditions about $40 \%$ of the population eat no animals (ibid.). In contrast, eating 
meat in China is still a symbol of wealth and prosperity, and thus meat consumption is increasing. Nevertheless, there is a small counter-tendency, in particular in big cities, where small vegetarian and even vegan movements can be observed. Today $4 \%$ to $5 \%$ of the Chinese eat vegetarian (http:// www.pri.org/stories/2013-06-27/vegan-lunch-going-meatless-beijing).

\section{German Nutrition Styles}

Although some general trends in dietary patterns are emerging, there are still large differences in individual nutrition and consumption habits. Individual eating habits are influenced by diverse factors. These include among other factors the availability and accessibility of food, physiological needs and recommendations given in this context, personal experience, knowledge and competence, preferences and tastes, cultural and family traditions, and societal norms, but also more general factors like time, financial availability, and domestic constraints resulting from household decision making or working patterns (Stieß/Hayn 2005; Reisch et al. 2013).

Within a study on behalf of the German Ministry of Education and Research diets, the eating and consumption habits of German consumers have been investigated. To this end, a representative analysis (sample $>2,000$ ) was carried out in order to cluster consumers into groups of different nutrition styles ${ }^{3}$. For Germany seven nutrition styles have been identified (Stieß/Hayn 2005; Eberle/Hayn 2006):

- The "disinterested fast fooder" (12\%) are mostly young singles and couples, in a pre-family life phase aged up to 35 years. They have little interest in nutrition and health, or cooking. Eating takes place mainly out of home in canteens or fast-food restaurants. Fresh food such as fruits and vegetables are consumed very seldom, while meat and products with constitutional additives are eaten at an above average rate.

- In the everyday life of the "low budget and meat eaters" (13\%), nutrition and health also play a secondary role. Nutrition has to be mainly cheap and straightforward. They cook only occasionally and use often ready-made meals. Meat is looked at as ideal food because it is simple to cook. Fresh food like fruits and vegetables are consumed very seldom.

- The "joyless cooks by habit" (17\%) are mostly elderly with firmly fixed eating habits and low nutritional awareness. They seldom eat out, and daily routines like cooking and eating together structure their everyday life although they do not enjoy eating at all.

- In contrast, the "fitness-orientated ambitious" (9\%) aim to maintain their physical capacity and fitness through a high-quality diet. Thus, high-quality and constitutional food but also functional food play an important role in their nutrition. Nevertheless, their nutrition decisions follow pragmatic compromises. The "fitness-orientated ambitious" are mostly middle-aged couples with and without children, often both working with an income higher than average.

- The nutrition style of the "stressed managers of everyday's life" (16\%) mainly consists of women who have the exclusive responsibility for the alimentation of the whole family. They are very much interested in healthy nutrition and diversified cooking with fresh products is important for them. But they act in a permanent dilemma between their own ambitions and the requirements of everyday life. Load removal options such as ready-made meals foil their own ambitions and are usually also too expensive.

- The "nutritional consciously ambitious" $(13 \%)$ are also very much interested in nutrition and health and are highly motivated to nourish sustainable. Quality, fresh products, and locally grown natural food are very important to them. They appreciate organically grown food and detest synthetic additives. They eat many fruits and vegetables and consume little meat. This nutrition style is not correlated with a life phase or an age group.

- The nutrition style of the "conventional health orientated" (20\%) was the most frequently found one in Germany. They appreciate good food and are very much interested in nutrition. They like cooking and do it very often. Unfortunately the pleasure they have eating is troubled by being overweight and having 
health problems. Hence, they are struggling to fulfill their own ambition to eat less meat and sweets. The "conventional health orientated" are mostly elderly in the after-family phase.

Different nutrition styles have different types of an environmental impacts, which are mainly influenced by the dietary composition. As mentioned above, particularly the share of animal-derived products is crucial. But other factors like the energy efficiency status of domestic appliances for storing and cooking food, the chosen means of transport for the shopping trip, or the share of inhouse and out-of-home food consumption have a substantial impact on the environmental burden (Eberle et al. 2006). With regard to the German nutrition styles identified in the study of Eberle/ Hayn 2006, the "disinterested fast fooder" has the highest environmental impacts. This is mainly due to a high share of out-of-home consumption, which on average has a higher environmental impact than in-house food consumption because of the meal composition (higher share of meat) and higher use of energy for meal preparation and room climate than in households. The lowest environmental burden is related to the nutrition style of the "joyless cooks by habit". The difference between these two extremes in terms of greenhouse gas emissions is $25 \%$. Remarkable is that the nutrition style of the "nutritional consciously ambitious" is indeed related to lower environmental impacts, but not with the lowest. Despite the fact that they are the only ones who are very aware of the health and environmental concerns and thus have the highest share in organically grown food in their diet, two other nutrition styles have lower environmental burdens: the "joyless cooks by habit" and the "conventional health orientated". The reason is the much lower out-of-home consumption share of both nutrition styles (Wiegmann et al. 2005; Hayn et al. 2006; Eberle et al. 2006). As already indicated by the above discussed opposing tendencies in diets, it can be assumed that the relative shares of the nutrition styles within the population and their characteristics will evolve over time. However, it is not possible to derive any conclusions about the further development of nutrition styles and the related impact on health and the environment from the inquiry. Further research on these aspects is needed.

\section{Paths Towards Sustainable Food Consumption}

It is obvious that the predominant consumption habits in industrialised countries are not sustainable at all, neither regarding individual and public health nor with respect to environmental and global justice (Eberle et al. 2006; SDC 2009; Reisch et al. 2013). But why don't we change our dietary patterns and switch to a more sustainable nutrition and food consumption, one which is environmental friendly, constitutional and healthy?

First of all, it is essential to recognise that it must be possible to implement strategies for a more sustainable nutrition and food consumption, if they aim to have success, in everyday life and that they have to take socio-cultural diversity of diets and eating habits into consideration. There is not only one path towards sustainable food consumption and thus not only one diet that is sustainable. But it is well known that a reduction in consumption of animal-based food is crucial - for the reduction of environmental burdens as well as for lessening of negative health impacts, e.g. due to the high intake of saturated fat. In some countries, for instance in Germany, it can be observed that nutrition and food is not really cherished (Stieß/Hayn 2005; Eberle/Hayn 2006), neither as food products nor with respect to culinary culture nor regarding the work that is associated with eating such as shopping or storing and preparing food. The strategies for sustainable nutrition and food consumption should therefore take into consideration how they can make use of opposing societal tendencies like vegetarianism, veganism, or slow food.

The development of strategies for a more sustainable nutrition and food consumption have to take further trends into account, such as the demand for highly processed fast food, for convenience food, and for eating out, as well as the fact that the time spent for purchasing food and for eating has diminished over recent years and that housekeeping competence has decreased. Thus, it is essential to take the whole system and its interdependencies into account and not to develop single issue-orientated strategies, for instance just aiming to reduce green house gas emissions of food or to change diets. Keeping this in mind, Eberle et al. (2006) identified four principles to 
which actions for achieving sustainable nutrition and food consumption have to be aligned:

- Sharing responsibility among all players in society: Sustainable nutrition and food consumption is a societal task, to which all players have to contribute, from politics to agriculture, food processing companies, retailers and consumers.

- Encouraging competence: To take responsibility for sustainable nutrition and food consumption implies that all players have the appropriate competence, meaning the ability to transfer theoretical knowledge and practical skills into adequate actions. The lack of such competences in private and professional action is a major barrier to more sustainable nutrition. This includes that nutritional competence are not passed on adequately.

- Bundle sustainability qualities in food supply: A shift towards sustainable nutrition requires easy access to sustainable food. Thus, sustainable food consumption requires food products and services that are constitutional, environmentally friendly, and ethically responsible. These products and services have to be appropriate for everyday life and have to fit the different daily routines of consumers. At the same time they have to allow socio-cultural diversity. Nowadays only one or two aspects of sustainability are usually addressed, e.g. organically grown and fair traded food or organically grown convenience food. Sustainable food consumption requires that it is easy for consumers to make sustainable choices.

- Constitute an adequate framework: A shift towards sustainability calls for a coherent set of European and German policies that facilitates and guides societal transformation processes.

In Germany, the burden on and overloading of consumers but also the lacking competence or willingness of professional players in the food chain constitute central barriers to a shift to more sustainable food consumption and thus also constitute a central starting point for strategies (Eberle et al. 2006; Eberle et al. 2011). With regarding to consumers, this overload results in a wish for simplification and a removal of stress which cannot be discredited only as being accommodativeness. Nutrition nowadays is a complex task. The overwhelming range of offers of food products and services as well as the information overload that is sometimes even contradictory and often not transparent make decision making a challenge. There are furthermore the financial constraints, the everyday time frame, the preferences of household members, and job-related and leisure-related requirements that have to be managed. Since the extent of the overload varies from nutrition style to nutrition style as do the reasons for it, differentiated measures have to be applied to overcome it. Knowledge of the specifics of the different nutrition styles forms the basis for this.

Another important barrier in Germany is the lack of appreciation of nutrition and food (Eberle et al. 2006; Eberle/Hayn 2007). The price of food seems to be more important than the quality of the products. At the same time, the prices for food and the share of disposal household income spent on food have decreased significantly during the past decades (Hünecke et al. 2004). This is one reason for the declining appreciation of food; another is the fact that consumers today are estranged from agricultural production and food processing. This barrier differs in the seven German nutrition styles. Consequently, strategies for sustainable nutrition and food consumption have to be specified to the different nutrition styles and consumer groups. There is no general and universally valid strategy.

\section{Outlook}

It is predicted that sustainability problems related to food consumption will globally become more serious in the future. This is the result of changing dietary patterns with a higher share in animal-derived products, population growth, and rising economic prosperity but also of climate change affecting agricultural production, increasing land use conflicts, growing health problems and costs (Reisch et al. 2013).

Whether this development can be slowed by opposing tendencies like slow food, organic agriculture and vegetarianism is difficult to predict. Given the negative environmental and health impacts of the prevailing dietary patterns in industrialised countries, a shift towards sustainable food consumption is urgently needed. The appropriate measures for promoting a greater appreciation of 
food, changes in dietary patterns and a growing respect for animals, nature and the environment have to be implemented. Sustainable food choices should become the standard in the near future.

\section{Notes}

1) All data regarding meat and milk consumption have been taken from http://www.who.int/nutrition/topics/3 foodconsumption/en/index4.html (download 26.5.14).

2) GHG emissions from private households include amongst others emissions for transport, energy consumption for electricity and heating, food consumption and consumption of textiles. Indirect emissions from agricultural production are not included.

3) It has to be noticed that nutrition styles are not the same as diets like vegetarianism or wholefoods.

\section{References}

Badenschier, F.; Bartz, D.; Benning, R. et al., 2013: Fleischatlas. Daten und Fakten über Tiere als Nahrungsmittel. Heinrich Böll Stiftung, Bund für Umweltund Naturschutz und Le Monde diplomatique

Bauhus, J.; Christen, O.; Dabbert, S. et al., 2012: Ernährungssicherung und nachhaltige Produktivitätssteigerung. Wissenschaftlicher Beirat für Agrarpolitik beim Bundesministerium für Ernährung, Landwirtschaft und Verbraucherschutz (BMELV)

BMELV - Bundesministerium für Ernährung, Landwirtschaft und Verbraucherschutz (ed.), 2010: Statistisches Jahrbuch über Ernährung, Landwirtschaft und Forsten 2010. Bremerhaven

Cordts, A.; Spiller, A.; Nitzko, S. et al., 2013: Imageprobleme beeinflussen den Konsum. Von unbekümmerten Fleischessern, Flexitariern und (Lebensabschnitts-) Vegetariern. In: Fleischwirtschaft 7 (2013), p. 59

Eberle, U., 2012: Alles jederzeit verfügbar. Lebensmittel auf Weltreise. In: Not für die Welt. Ernährung im Zeitalter der Globalisierung. Gütersloh, pp. 96-129 Eberle, U.; Fels, J., 2014a: Environmental Impacts of German Food Consumption and Food Losses. Paper for the 9th International Conference LCA of Food San Francisco, USA 810 October 2014 (in preparation)

Eberle, U.; Fels, J., 2014b: Abschätzung der Umweltrelevanz von Lebensmittelprodukten. In: Jepsen, D.; Eberle, U. (eds.): Entwicklung von Instrumenten zur Vermeidung von Lebensmittelabfällen, with collaboration of Fels J, Schomerus T, on behalf of the Federal German Environmental Agency (in preparation)
Eberle, U.; Fritsche U.R.; Hayn, D. et al., 2004: Beschreibung der Dynamiken eines gesellschaftlichen Handlungsfelds. Ernährungswende-Discussionspaper No. 1, Freiburg

Eberle, U.; Hayn, D., 2007: Ernährungswende. Eine Herausforderung für Politik, Unternehmen und Gesellschaft. Freiburg

Eberle, U.; Hayn, D.; Rehaag, R., et al., 2006: Ernährungswende. Eine Herausforderung für Politik, Unternehmen und Gesellschaft. Munich

Eberle, U.; Spiller, A.; Becker, T. et al., 2011: Joint Statement of the Scientific Advisory Board on Consumer and Food Policy and on Agricultural Policy at the Federal Ministry of Food, Agriculture and Consumer Protection. Political Strategy for Food-Labelling. Berlin EEA - European Environmental Agency, 2005: Household Consumption and the Environment. EEA Report No. 11/2005. Copenhagen

FiBL - Research Institute of Organic Agriculutre; Ifoam - International Federation of Organic Agriculture Movements, 2014: The World of Organic Agriculture. Statistics and Emerging Trends 2014. Bonn

Hamermesh, D., 2007: Time to Eat: Household Production under Increasing Income Equality. In: American Journal of Agricultural Economics 89/4 (2007), pp. $852-863$

Hawkes, C.; Chopra, M.; Friel, S. et al., 2007: Globalization, Food and Nutrition Transitions. WHO Commission on Social Determinants of Health. Globalization and Health Knowledge Network: Research Papers, Ottawa

Hayn, D.; Eberle, U.; Stieß, I. et al., 2006: Ernährung im Alltag. In: Eberle, U.; Hayn, D.; Rehaag, R. et al. (eds.): Ernährungswende. Eine Herausforderung für Politik, Unternehmen und Gesellschaft. Munich, pp. 73-84

Hirschfelder, G., 2001: Europäische Esskultur. Eine Geschichte der Ernährung von der Steinzeit bis heute. Frankfurt a. M.

HLPE - High Level Panel of Experts on Food Security and Nutrition, 2014: Note on Critical and Emerging Issues for Food Security and Nutrition. Rome; http:// www.fao.org/fileadmin/user_upload/hlpe/hlpe_documents/Critical_Emerging_Issues/HLPE_Note-toCFS_Critical-and-Emerging-Issues_6-August-2014. pdf (download 31.10.14)

Hünecke, K.; Fritsche, U.F.; Eberle, U., 2004: Lebenszykluskosten für Ernährung. Ernährungswende Discussion Paper No. 2. Darmstadt

Kastner, T.; Ibarrola Rivas, M.J.; Koch, W. et al., 2012: Global Changes in Diets and The Consequences 
for Land Requirements for Food. In: PNAS 18/2012, pp. 6868-6872

Kearney, J., 2010: Food Consumption Trends and Drivers. In: Philosophical Transacations of the Royal Society of London Series B-Biological Sciences 365 (2010), pp. 2793-2807; http://rstb.royalsocietypublishing.org/ content/365/1554/2793.full.pdf (download 10.10.14)

Kranert, M.; Hafner, G.; Barabosz, J. et al., 2012: Ermittlung der weggeworfenen Lebensmittelmengen und Vorschläge zur Verminderung der Wegwerfrate bei Lebensmitteln in Deutschland. Institut für Siedlungswasserbau, Wassergüte- und Abfallwirtschaft. Stuttgart

Meier, T., 2014: Umweltschutz mit Messer und Gabel. Der ökologische Rucksack der Ernährung in Deutschland. Munich

Mendez, M.A.; Popkin, B.M., 2004: Globalization, Urbanization and Nutritional Change in The Developing World. In: Electronic Journal of Agricultural and Development Economics 1/2 (2004), pp. 220-241; http:// www.cpc.unc.edu/projects/nutrans/publications/ Mendez-Globalization-Urbanization-eJADE2005.pdf (download 10.10.14)

Meyer, R.; Priefer, C., 2012: Ökologischer Landbau und Bioenergieerzeugung. Zielkonflikte und Lösungsansätze. TAB-Arbeitsbericht Nr. 151, Büro für Technikfolgen-Abschätzung beim Deutschen Bundestag, Berlin

Millstone, E.; Lang, T., 2008: The Atlas of Food. London

Naska, A.; Fouskakis, D.; Oikonomou, E. et al., 2006: Dietary Patterns and Their Socio-demographic Determinants in 10 European Countries: Data From the DAFNE Databank. In: European Journal of Clinical Nutrition 60 (2006), pp. 181-190

Nellemann, C.; MacDevette, M.; Manders, T. et al. (eds.), 2009: The Environmental Food Crisis - The Environment's Role in Averting Future Food Crisis. A UNEP rapid response assessment. United Nations Environment Programme (UNEP), GRID-Arendal

OECD - Organization for Economic Cooperation and Development, 2010: Obesity and The Economics of Prevention: Fit not Fat. Paris

OECD - Organization for Economic Cooperation and Development; FAO - Food and Agricultural Organization of the United Nations, 2011: OECD-FAO Agricultural Outlook 2011-2020. Paris

Oosterveer, P.; Sonnenfeld, D., 2012: Food. Globalization, and Sustainability. New York

Popkin, B.M., 2002: The Shift in Stages of the Nutrition Transition in the Developing World differs from Past Experiences! In: Malaysian Journal of Nutrition 8/1 (2002), pp. 109-124
Reisch, L.; Eberle, U.; Lorek, S., 2013: Sustainable Food Consumption: An Overview of Contemporary Issues and Policies. In: Sustainability: Science, Practice \& Policy 9/2 (2013), pp. 7-25

Scarborough, P.; Appleby, P.; Mizdrak, A. et al., 2014: Dietary Greenhouse Gas Emissions of Meat-eaters, Fish-eaters, Vegetarians and Vegans in the UK. Climatic Change, doi: 10.1007/s10584-014-1169-1

Schaffnit-Chatterjee, C., 2009: The Global Food Equation: Food Security in an Environment of Increasing Scarcity. Deutsche Bank Research, Frankfurt a. M.

Schmidhuber, J.; Traill, W.B., 2005: The Changing Structure of Diets in the European Union in Relation to Healthy Eating Guidelines. Public Health Nutrition 9/5 (2005), pp. 584-595

SDC - Sustainable Development Commission, 2009: Setting the Table: Advice to Government on Priority Elements of Sustainable Diets. London

Stieß, I.; Hayn, D., 2005: Ernährungsstile im Alltag. Ergebnisse einer repräsentativen Untersuchung. In colaboration with Götz, K.; Schubert, S.; Seltmann, G.; Birzle Harder, B.; Institute for social-ecological Research, Frankfurt a. M.

UN - United Nations, 2013: Goal 1: Eradicate Extreme Poverty \& Hunger. Factsheet 2013; http://www. un.org/millenniumgoals/pdf/Goal_1_fs.pdf (download 10.10.14)

WHO - World Health Organization, 2005: The European Health Report 2005: Public Health Action for Healthier Children and Populations. Copenhagen

Wiegmann, K.; Eberle, U.; Fritsche, U.R. et al., 2005: Umweltauswirkungen von Ernährung. Stoffstromanalysen und Szenarien. Discussion Paper „Ernärungswende“", No. 7, Darmstadt

\section{Contact}

Dr. Ulrike Eberle

corsus - corporate sustainability

Nernstweg 32-34, 22765 Hamburg

Phone: +49 40 398084-76

Email: u.eberle@corsus.de 